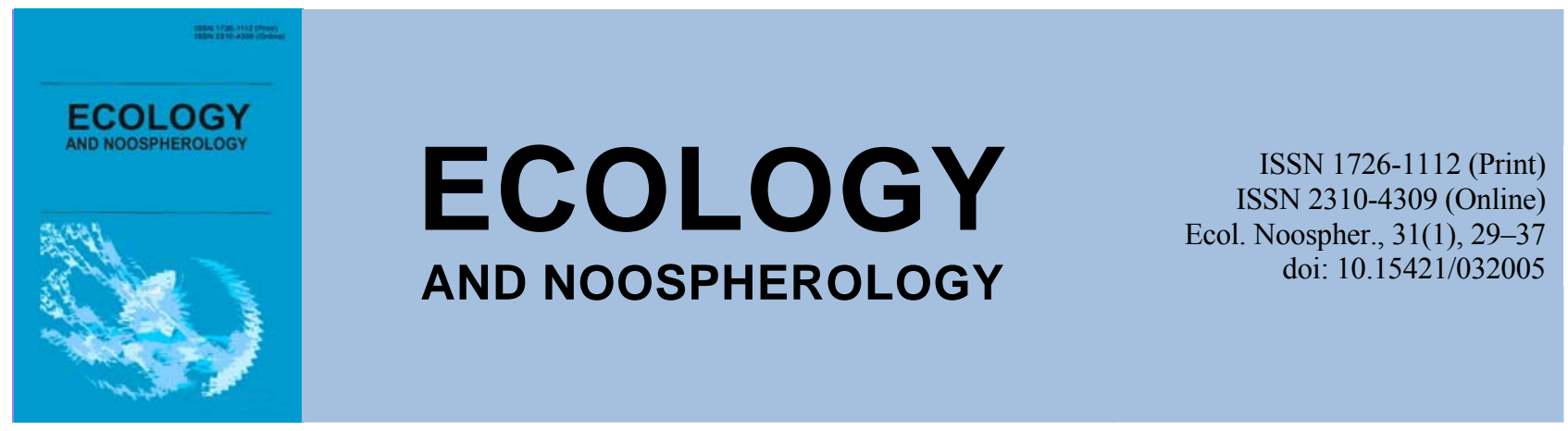

\title{
Current state of wheat insects entomofauna in Dnepropetrovsk, Zaporizhia and Poltava regions
}

\author{
T. M. Kolombar, D. V. Maslova
}

Oles Honchar Dnipro National University, Dnipro, Ukraine

Article info

Received 14.04.2020

Received in revised form

19.04.2020

Accepted 27.04.2020

Oles Honchar Dnipro

National University,

Gagarin Ave., 72, Dnipro,

49010, Ukraine.

Tel.: +38-095-370-59-00

E-mail:t_kolombar@i.ua
Kolombar, T. M., \& Maslova, D. V. (2020). Current state of wheat insects entomofauna in Dnepropetrovsk, Zaporizhia and Poltava regions. Ecology and Noospherology, 31(1), 29-37. doi:10.15421/032005

Cereals are the basis of world crop production. In Ukraine, winter wheat crop plays a rolea strategic agricultural product. The basis of food security and the formation of the national export potential depend on this crop species. Wheat has a steadydemand on the internal and foreign markets. In the structure of crops, it occupies about 6 million hectares, which is more than $22 \%$ of all cultivated areas and almost $42 \%$ of grain crops. Like most other crops, cereals serve as food supply for a wide range of insect phytophages. Conventionally, the entire fauna of endangeredspecies can be divided into multiphages, oligophages and monophages. Cereal plants are damaged by insects during the entire growing season, from germination to harvesting. There are more than 230 species of wheat insects. Territory of the steppe zone of Ukraineamounted 17 most common and criticallyendangeredspecies on. The degree of harmfulness of each species in different vegetation periods is not the same. The goal of the paper was to reveal a current state of the most common endangeredspecies (wheat phytophages) within Dnepropetrovsk, Poltava and Zaporizhia Oblasts, and to assess a degree of their harmfulness (according to literature data). Harmful insects were accounted using conventional manual sampling method. The accounting was carried out on plots of $50 \times 50 \mathrm{~cm}\left(0.25 \mathrm{~m}^{2}\right)$, staggered evenly over an entire field, using a frame placed onto the plants randomly. All wheat stems inside the frame were shaken to a ground surface, and the number of harmful insects was counted. At the same time, the upper layer of soil $(0-25 \mathrm{~cm})$ was visually inspectedfor the presence of insect larvae and imagos. 16 samples were collectedon each field. The average number of each insect species per $1 \mathrm{~m}^{2}$ of wheat crops was calculated. As a result of 50 fields survey in Dnepropetrovsk, Zaporizhia and Poltava Oblast, a list of the most common endangeredspecies (wheat phytophages) in the steppe and forest-steppe zones was created. It includes 17 species belonging to 7 families from three orders. The most recorded representatives of Coleoptera order were 12 species, four species from Hemiptera order and one from Thysanoptera. On average, three species of wheat phytophages belong to each of the families; the largest number of endangeredspecies is represented by Scarabaeidae family. Among the identified phytophages, the most common were Harpalus rufipes (De Geer, 1774) 88\% of infected fields, Zabrus tenebrioides (Goeze, 1777) 78\% and Anisoplia austriaca (Herbst, 1783) 72\%. Specimenof endangeredspecies as Eurygaster integriceps (Puton, 1881) were found on 34 fields, Haplothrips tritici (Kurdjumov, 1912) on 22 fields, Oulema lichenis (Heyden, 1879) on 21 fields, and Aelia acuminata (Linnaeus, 1758) on 18 fields. A brief description of each of 17 endangeredspecies was presented, taking into account their harmfulness in different periods of wheat vegetation. The degree of harmfulness of each species in different vegetation periods is not a same. A distinction is made between the early period, spring and the second half of the growing season. Early vegetation period is from the seedling emergence to the period of grass tillering. During this period, an impact of harmful insects is particularly dangerous, and a damage they cause can lead to a death of plants over large areas. The species most dangerous for wheat at this time are Harpalus rufipes and Zabrus tenebrioides. It is difficult to establish a clear distinction between the impact of endangeredspecies on plants during different periods of vegetation. With a beginning of spring vegetation, Oulema lichenis, Phyllotreta vittula and Chaetocnema aridula and Tropinota hirta are added to the above-mentioned species. Harmfulness during this period consists will be represented by leaf blade damage. The middle of vegetation coincides with an ear formation and grain filling phases. The most active endangeredwheat species during this period are considered to be Haplothrips tritici, Opatrum sabulosum, Pedinus femoralis and Blaps lethifera. The quality indicators of a cereal crop yield are reduced by Eurygaster integriceps and E. maura, Aelia acuminata and A. rostrata. Before the 
harvest the grain is damaged by various Scarabaeidae, in particular Anisoplia austriaca, A. agricola, A. segetum. As a result of controlling the number and species composition of endangeredwheat species, it is necessary to adapt the application of integrated methods of wheat protection to the soil and climatic conditions of the steppe and forest-steppe zones of Ukraine.

Keywords: harmfulness; endangeredwheat species; entomofauna; biological methods; plant protection

\title{
Сучасний стан ентомофауни шкідників - фітофагів пшениці у Дніпропетровській, Запорізькій та Полтавській областях
}

\author{
Т. М. Коломбар, Д. В. Маслова \\ Дніпровський національний університет імені Олеся Гончара, Дніпро, Україна
}

В Україні озима пшениця є стратегічним видом агропродукції. Від цієї культури залежить основа продовольчої безпеки та формування експортного потенціалу держави. Основне виробництво озимої шениці зосереджено в центральних регіонах України. Як і більшість інших культур, зернові злаки є їжею для широкого кола фітофагів. Мета статті - охарактеризувати сучасний стан ентомофауни шкідників - фітофагів пшениці на території Дніпропетровської, Полтавської та Запорізької областей та оцінити ступінь їх шкодочинності (за літературними даними). У результаті обстеження 50 полів сформовано список найпоширеніших шкідників - фітофагів пшениці степової та лісостепової зони. Він включає 17 видів, які належать до 7 родин 3 трьох рядів. Розраховано середню чисельність комах кожного виду на $1 \mathrm{~m}^{2}$ посівів пшениці. Серед виявлених фітофагів найчастіше зустрічаються турун волосистий Harpalus rufipes (De Geer, 1774) - 88 \% заражених полів, турун хлібний Zabrus tenebrioides (Goeze, 1777) - 78 \% та хлібний жук-кузька Anisoplia austriaca (Herbst, 1783) - 72 \%. На 34 полях виявлені представники виду клоп шкідлива черепашка Eurygaster integriceps (Puton, 1881), на 22 - пшеничний трипс Haplothrips tritici (Kurdjumov, 1912), на 21 - п'явиця синя Oulema lichenis (Heyden, 1879) та на 18 - елія гостроголова Aelia acuminata (Linnaeus, 1758). Наведено коротку характеристику кожного 317 видів шкідників 3 урахуванням їх шкодочинності в різні періоди вегетації пшениці. У результаті контролю чисельності та видового складу шкідників фітофагів пшениці необхідно адаптувати застосування інтегрованих методів захисту пшениці до грунтово-кліматичних умов степової та лісостепової зони України.

Ключові слова: шкодочинність; шкідники пшениці; ентомофауна; біологічні методи; захист рослин

\section{Вступ}

Зернові складають основу рослинництва всього світу. В Україні озима пшениця $\epsilon$ стратегічним видом агропродукції. Від цієї культури залежить основа продовольчої безпеки та формування експортного потенціалу держави. Пшениця користується постійним попитом на внутрішньому та зовнішньому ринках. У структурі посівів вона займає близько 6 млн га, що становить понад $22 \%$ усіх посівних площ та майже $42 \%$ посівів зернових культур (Maslak et al., 2016). Основне виробництво озимої пшениці зосереджено в центральних регіонах України. Так, за даними Державної служби статистики України, більше за інших у 2018-2019 роках зібрали пшениці у Харківській, Дніпропетровській, Запорізькій та Полтавській областях.

Як і більшість інших культур, зернові злаки є їжею для широкого кола фітофагів. Умовно всю фауну шкідників можна поділити на багатоїдних, олігофагів і монофагів (Halimonik, 2005; Getman, 2008). Злакові рослини пошкоджують протягом усього періоду вегетації - від проростання до збирання врожаю. Зародком проростаючого зерна живляться дротяники, личинки росткової мухи. Гусениці підгризаючих совок, личинки пластинчастовусих жуків і хлібного вусача перегризають молоді проростки, що часто призводить до значного зрідження посівів. На молодих сходах оселяються личинки злакових мух, які пошкоджують точку росту, стебло, центральний листок, від чого рослини засихають. Восени значної шкоди молодим рослинам завдають личинки хлібних жужелиць та озимої совки. Пошкоджень, зовні схожих на випрівання озимих, завдає зимовий злаковий кліщ. Навесні сходами ярих хлібів живляться жуки смугастої хлібної блохи, злакові мухи, цикадки. На листках розвиваються і шкодять попелиці, трипси, клопичерепашки, личинки пильщиків, п'явиці, мухи-мінери тощо. Кореневу систему підгризають личинки пластинчастовусих жуків, кореневі попелиці (Vasilev, 1989; Romanenko et al., 2001; Vereshagin, 2001 Orlov, 2006). Шкідників пшениці понад 230 видів. До найбільш поширених і небезпечних належать на території степової зони України 17 з них. Ступінь шкодочинності кожного виду в різні періоди вегетації неоднакова (Romanenko et al., 2001). Тому мета статті - охарактеризувати сучасний стан ентомофауни шкідників - фітофагів пшениці у Дніпропетровській, Полтавській та Запорізькій областях та оцінити ступінь їх шкодочинності (за літературними даними).

\section{Матеріали та методи досліджень}

Протягом 2018-2019 років обстежено 50 полів озимої пшениці в 17 адміністративних районах Дніпропетровської, Запорізької та Полтавської областей (табл. 1).

Облік шкідливих комах проводили традиційним методом ручного розбирання проб. На ділянках $50 \times 50 \mathrm{~cm}$ $\left(0,25 \mathrm{M}^{2}\right)$, розміщених у шаховому порядку рівномірно на всьому полі, проводили облік за допомогою рамки, яку накладали на рослини випадково. Усі стебла всередині рамки струшували на землю і підраховували кількість шкідників. При цьому оглядали верхній шар грунту (0-25 см) на наявність личинок та імаго комах. На кожному полі брали 16 проб. У результаті встановлювали середню чисельність шкідників на $1 \mathrm{~m}^{2}$ посіву.

Видовий склад шкідників встановлювали за допомогою визначників комах (Bej-Bienko, 1964). Статистичну обробку результатів проводили в пакеті програм Statistica 8.0 (Statsoft Inc., USA). Дані в таблиці представлені у вигляді $\mathrm{x} \pm \mathrm{SD}$.

\section{Результати та їх обговорення}

У результаті обстеження 50 полів Дніпропетровської, Запорізької та Полтавської областей сформовано список 
Таблиця 1

Обстежені 50 агроценозів Дніпропетровської, Запорізької та Полтавської областей

\begin{tabular}{|c|c|c|c|c|c|}
\hline \multicolumn{3}{|c|}{ Розташування сільськогосподарського угіддя } & \multicolumn{2}{|c|}{ Дата обстеження } & \multirow{2}{*}{$\begin{array}{l}\text { Умовна } \\
\text { позначка }\end{array}$} \\
\hline Область & Район & GPS-координати & рік & місяць & \\
\hline \multirow[t]{32}{*}{ Дніпропетровська } & Апостолівський & $47,5115 \mathrm{~N} \mathrm{33,5922 \textrm {E }}$ & 2018 & Березень & Д.1.1 \\
\hline & & $47,8402 \mathrm{~N} 33,9379 \mathrm{E}$ & 2018 & Березень & Д.1.2 \\
\hline & Дніпровський & $48,3630 \mathrm{~N} 35,2310 \mathrm{E}$ & 2018 & Березень & Д.2.1 \\
\hline & & $48,3488 \mathrm{~N} \mathrm{35,1030 \textrm {E }}$ & 2018 & Березень & Д.2.2 \\
\hline & & $48,3310 \mathrm{~N} \mathrm{35,0531 \textrm {E }}$ & 2018 & Березень & Д.2.3 \\
\hline & & 48,4706 N 35,2977 E & 2018 & Березень & Д.2.4 \\
\hline & Криворізький & $47,9645 \mathrm{~N} 33,6585 \mathrm{E}$ & 2018 & Квітень & Д.3.1 \\
\hline & & 47,9492 N 33,6629 E & 2018 & Квітень & Д.3.2 \\
\hline & & $47,9969 \mathrm{~N} \mathrm{33,5641 \textrm {E }}$ & 2018 & Квітень & Д.3.3 \\
\hline & & $47,9857 \mathrm{~N} 33,3642 \mathrm{E}$ & 2018 & Квітень & Д.3.4 \\
\hline & Нікопольський & $47,8556 \mathrm{~N} 34,2141 \mathrm{E}$ & 2018 & Квітень & Д.4.1 \\
\hline & & $47,9320 \mathrm{~N} \mathrm{34,1912} \mathrm{E}$ & 2018 & Квітень & Д.4.2 \\
\hline & & $47,8981 \mathrm{~N} 34,4269 \mathrm{E}$ & 2018 & Квітень & Д.4.3 \\
\hline & Новомосковський & $48,7087 \mathrm{~N} \mathrm{35,3462} \mathrm{E}$ & 2018 & Травень & Д.5.1 \\
\hline & & $48,7703 \mathrm{~N} 35,4522 \mathrm{E}$ & 2018 & Травень & Д.5.2 \\
\hline & & $48,7995 \mathrm{~N} 35,2110 \mathrm{E}$ & 2018 & Травень & Д.5.3 \\
\hline & Павлоградський & $48,6303 \mathrm{~N} \mathrm{36,2327} \mathrm{E}$ & 2018 & Травень & Д.6.1 \\
\hline & & 48,5748 N 36,2294 E & 2018 & Травень & Д.6.2 \\
\hline & & $48,5542 \mathrm{~N} 36,2265 \mathrm{E}$ & 2018 & Травень & Д.6.3 \\
\hline & & $48,6299 \mathrm{~N} 35,8247 \mathrm{E}$ & 2018 & Травень & Д.6.4 \\
\hline & Петриківський & $48,7458 \mathrm{~N} 34,5361 \mathrm{E}$ & 2018 & Червень & Д.7.1 \\
\hline & & $48,7382 \mathrm{~N} 34,5528 \mathrm{E}$ & 2018 & Червень & Д.7.2 \\
\hline & & $48,7023 \mathrm{~N} \mathrm{34,8433 \textrm {E }}$ & 2018 & Червень & Д.7.3 \\
\hline & & $48,6908 \mathrm{~N} 34,8224 \mathrm{E}$ & 2018 & Червень & Д.7.4 \\
\hline & Синельниковський & $48,3223 \mathrm{~N} \mathrm{35,2624} \mathrm{E}$ & 2018 & Жовтень & Д.8.1 \\
\hline & & $48,3280 \mathrm{~N} \mathrm{35,2781 \textrm {E }}$ & 2018 & Жовтень & Д.8.2 \\
\hline & & $48,3194 \mathrm{~N} 35,2884 \mathrm{E}$ & 2018 & Жовтень & Д.8.3 \\
\hline & Солонянський & $48,2683 \mathrm{~N} 34,7714 \mathrm{E}$ & 2018 & Жовтень & Д.9.1 \\
\hline & & $48,2669 \mathrm{~N} 34,7857 \mathrm{E}$ & 2018 & Жовтень & Д.9.2 \\
\hline & Магдалинівський & 48,7726 N 34,8492 E & 2018 & Травень & Д.10.1 \\
\hline & & $48,7539 \mathrm{~N} 34,8232 \mathrm{E}$ & 2018 & Травень & Д. 10.2 \\
\hline & & $48,7484 \mathrm{~N} 34,8176 \mathrm{E}$ & 2018 & Травень & Д.10.3 \\
\hline \multirow[t]{10}{*}{ Запорізька } & Вільнянський & $47,9379 \mathrm{~N} \mathrm{35,4743 \textrm {E }}$ & 2019 & Березень & 3.1 .1 \\
\hline & & $47,9198 \mathrm{~N} 35,4262 \mathrm{E}$ & 2019 & Березень & 3.1 .2 \\
\hline & Запорізький & $48,0429 \mathrm{~N} 34,9377 \mathrm{E}$ & 2019 & Травень & 3.2 .1 \\
\hline & & $48,0454 \mathrm{~N} 34,9616 \mathrm{E}$ & 2019 & Травень & 3.2 .2 \\
\hline & & $48,0401 \mathrm{~N} 35,0240 \mathrm{E}$ & 2019 & Травень & 3.2 .3 \\
\hline & & $48,0343 \mathrm{~N} 34,972 \mathrm{E}$ & 2019 & Травень & 3.2 .4 \\
\hline & Новомиколаївський & $47,8753 \mathrm{~N} 35,9705 \mathrm{E}$ & 2019 & Березень & 3.3 .1 \\
\hline & & $47,8686 \mathrm{~N} \mathrm{35,9816} \mathrm{E}$ & 2019 & Березень & 3.3 .2 \\
\hline & Приморський & $47,0125 \mathrm{~N} 36,3907 \mathrm{E}$ & 2019 & Травень & 3.4 .1 \\
\hline & & $47,0366 \mathrm{~N} \mathrm{36,4019 \textrm {E }}$ & 2019 & Травень & 3.4 .2 \\
\hline \multirow[t]{8}{*}{ Полтавська } & Глобинський & $49,3309 \mathrm{~N} 33,1996 \mathrm{E}$ & 2019 & Жовтень & $\Pi$ П.1.1 \\
\hline & & $49,3318 \mathrm{~N} \mathrm{33,230 \textrm {E }}$ & 2019 & Жовтень & П.1.2 \\
\hline & Кобеляцький & $49,1645 \mathrm{~N} \mathrm{34,1668} \mathrm{E}$ & 2019 & Червень & П.2.1 \\
\hline & & $49,1649 \mathrm{~N} 34,1636 \mathrm{E}$ & 2019 & Червень & $\Pi .2 .2$ \\
\hline & & $49,1626 \mathrm{~N} 34,1461 \mathrm{E}$ & 2019 & Червень & $\Pi .2 .3$ \\
\hline & Кременчуцький & $49,2410 \mathrm{~N} 33,4995 \mathrm{E}$ & 2019 & Березень & П.3.1 \\
\hline & & $49,2424 \mathrm{~N} 33,5029 \mathrm{E}$ & 2019 & Березень & П.3.2 \\
\hline & & $49,2602 \mathrm{~N} \mathrm{33,5333 \textrm {E }}$ & 2019 & Березень & П.3.3 \\
\hline
\end{tabular}

найпоширеніших шкідників - фітофагів пшениці степової та лісостепової зони. Він включає 17 видів, які належать до 7 родин з трьох рядів (табл. 2).

Найбільше зафіксовано представників ряду Coleoptera 12 видів, чотири види 3 ряду Hemiptera та один Thysanoptera. У середньому до кожної з родин належить по три види фітофагів пшениці, найбільшою кількістю видівшкідників представлена родина Scarabaeidae.

Серед виявлених фітофагів найчастіше зустрічаються турун волосистий Harpalus rufipes (De Geer, 1774) - 88 \% заражених полів, турун хлібний Zabrus tenebrioides (Goeze, $1777)$ - $78 \%$ та хлібний жук-кузька Anisoplia austriaca (Herbst, 1783) - 72 \%. На 34 полях виявлені клоп шкідлива черепашка Eurygaster integriceps (Puton, 1881), на 22 пшеничний трипс Haplothrips tritici (Kurdjumov, 1912), на 21 - п’явиця синя Oulema lichenis (Heyden, 1879) та елія гостроголова Aelia acuminata (Linnaeus, 1758) - на 18 (рис. 1.1). Чисельність цих видів на досліджених полях представлена в табл. 3-4 відповідно. Кількість виявлених представників інших 10 видів зазначена у табл. 5.

Ступінь шкодочинності кожного виду в різні періоди вегетації неоднакова. Розрізняють ранній період, весняний і другу половину вегетації (Vereshagin, 2001), але чіткого розмежовування між впливом на рослини шкідників різних періодів вегетації встановити важко. Ранній строк вегетаціїчас від появи сходів до періоду кущення; в цей період вплив шкідливих комах особливо небезпечний i пошкодження, які вони спричиняють, можуть призвести до загибелі рослин на великих площах (Vereshagin, 2001). Найнебезпечніші для пшениці в цей час туруни волосистий та хлібний. 
Таблиця 2

Перелік найпоширеніших (17 видів) шкідників пшениці на території Дніпропетровської, Запорізької та Полтавської областей

\begin{tabular}{|c|c|c|c|}
\hline \multirow{2}{*}{ Ряд } & \multirow{2}{*}{ Родина } & \multicolumn{2}{|c|}{ Вид } \\
\hline & & латинська назва & українська назва \\
\hline \multirow{12}{*}{ Coleoptera } & Tenebrionidae & Opatrum sabulosum (Linnaeus, 1761) & Мідляк піщаний \\
\hline & & Pedinus femoralis (Linnaeus, 1767) & Мідляк кукурудзяний \\
\hline & & Blaps lethifera (Marsham, 1802) & Мідляк широкогрудий \\
\hline & Scarabaeidae & Anisoplia austriaca (Herbst, 1783) & Кузька хлібний \\
\hline & & Anisoplia segetum (Herbst, 1783) & Красун, або хрущ польовий \\
\hline & & Anisoplia agricola (Poda, 1761) & Жук хрестоносець \\
\hline & & Tropinota hirta (Poda, 1761) & Оленка пухнаста \\
\hline & Carabidae & Harpalus rufipes (De Geer, 1774) & Турун волосистий \\
\hline & & Zabrus tenebrioides (Goeze, 1777) & Турун хлібний малий \\
\hline & Chrysomelidae & Oulema lichenis (Heyden, 1879) & П’явиця синя \\
\hline & & Chaetocnema aridula (Gyllenhal, 1827) & Велика стеблова блішка \\
\hline & & Phyllotreta vittula (Redtenbacher, 1849) & Смугаста хлібна блішка \\
\hline Thysanoptera & Phlaeothripidae & Haplothrips tritici (Kurdjumov, 1912) & Трипс пшеничний \\
\hline \multirow{4}{*}{ Hemiptera } & Pentatomidae & Aelia acuminata (Linnaeus, 1758) & Елія гостроголоваа \\
\hline & & Aelia rostrata (Fabricius, 1803) & Елія носата \\
\hline & Scutellaridae & Eurygaster integriceps (Puton, 1881) & Черепашка шкідлива \\
\hline & & Eurygaster maura (Linnaeus, 17580 & Маврська черепашка \\
\hline
\end{tabular}

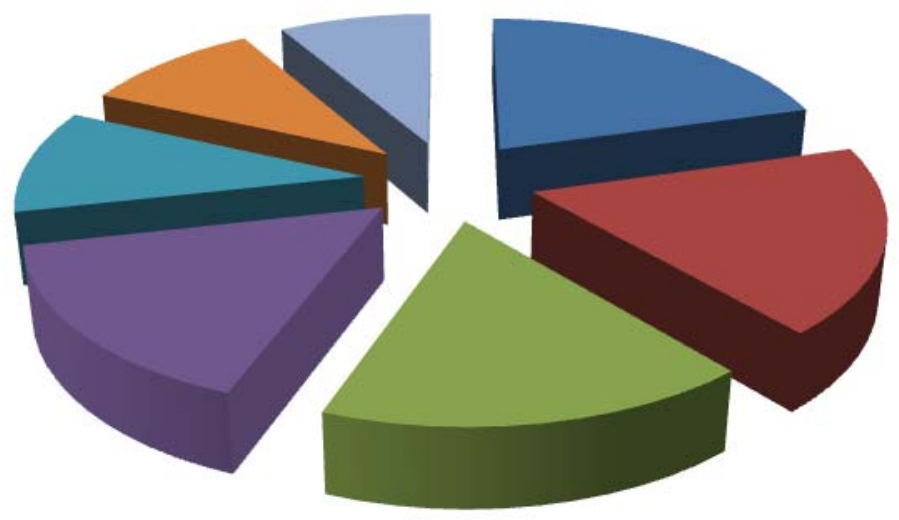

\section{- Harpalus rufipes}

- Zabrustenebrioides

- Anisopliacaustriaca

- Eurygaster integriceps

- Haplothrips tritici

- Oulemalichenis

- Aeliaacuminata

Рис. 1. Сумарна кількість шкідників пшениці на 50 досліджених полях Дніпропетровської, Запорізької та Полтавської областей

Таблиця 3

Чисельність (екз./м²) Harpalus rufipes (De Geer, 1774), Zabrus tenebrioides (Goeze, 1777), Anisoplia austriaca (Herbst, 1783) на дослідних полях Дніпропетровської, Запорізької та Полтавської областей $(\mathrm{x} \pm \mathrm{SD})$

\begin{tabular}{cccc}
\hline $\begin{array}{c}\text { Екосистема, умовна } \\
\text { позначка }\end{array}$ & Harpalus rufipes & Zabrus tenebrioides & Anisoplia austriaca \\
\hline 1 & 2 & 3 & 4 \\
\hline Д.1.1 & $0,016 \pm 0,061$ & $0,031 \pm 0,083$ & $0,031 \pm 0,121$ \\
Д.1.2 & $0,109 \pm 0,293$ & $0,078 \pm 0,211$ & $0,047 \pm 0,098$ \\
Д.2.1 & $0,000 \pm 0,000$ & $0,000 \pm 0,000$ & $0,000 \pm 0,000$ \\
Д.2.2 & $0,000 \pm 0,000$ & $0,141 \pm 0,250$ & $0,000 \pm 0,000$ \\
Д.2.3 & $0,344 \pm 0,458$ & $0,359 \pm 0,342$ & $0,094 \pm 0,174$ \\
Д.2.4 & $0,609 \pm 0,265$ & $0,469 \pm 0,329$ & $0,109 \pm 0,233$ \\
Д.3.1 & $0,297 \pm 0,494$ & $0,484 \pm 0,437$ & $0,125 \pm 0,217$ \\
Д.3.2 & $0,563 \pm 0,519$ & $0,641 \pm 0,353$ & $0,219 \pm 0,291$ \\
Д.3.3 & $0,125 \pm 0,293$ & $0,203 \pm 0,397$ & $0,063 \pm 0,188$ \\
Д.3.4 & $0,234 \pm 0,390$ & $0,188 \pm 0,337$ & $0,000 \pm 0,000$ \\
Д.4.1 & $0,297 \pm 0,478$ & $0,234 \pm 0,257$ & $0,109 \pm 0,216$ \\
Д.4.2 & $0,406 \pm 0,384$ & $0,203 \pm 0,309$ & $0,266 \pm 0,312$ \\
Д.4.3 & $0,484 \pm 0,640$ & $0,000 \pm 0,000$ & $0,016 \pm 0,061$ \\
Д.5.1 & $0,328 \pm 0,528$ & $0,516 \pm 0,488$ & $0,156 \pm 0,248$ \\
Д.5.2 & $0,125 \pm 0,217$ & $0,281 \pm 0,214$ & $0,000 \pm 0,000$ \\
Д.5.3 & $0,266 \pm 0,348$ & $0,109 \pm 0,197$ & $0,453 \pm 0,309$ \\
Д.6.1 & $0,313 \pm 0,410$ & $0,297 \pm 0,387$ & $0,203 \pm 0,283$ \\
Д.6.2 & $0,375 \pm 0,234$ & $0,422 \pm 0,229$ & $0,156 \pm 0,232$ \\
Д.6.3 & $0,078 \pm 0,192$ & $0,297 \pm 0,309$ & $0,234 \pm 0,272$ \\
Д.6.4 & $0,000 \pm 0,000$ & $0,000 \pm 0,000$ & $0,000 \pm 0,000$ \\
\hline
\end{tabular}




\begin{tabular}{|c|c|c|c|}
\hline 1 & 2 & 3 & 4 \\
\hline Д.7.1 & $0,031 \pm 0,083$ & $0,000 \pm 0,000$ & $0,141 \pm 0,250$ \\
\hline Д.7.2 & $0,234 \pm 0,348$ & $0,344 \pm 0,305$ & $0,297 \pm 0,426$ \\
\hline Д.7.3 & $0,375 \pm 0,545$ & $0,203 \pm 0,220$ & $0,422 \pm 0,229$ \\
\hline Д.7.4 & $0,000 \pm 0,000$ & $0,281 \pm 0,232$ & $0,031 \pm 0,083$ \\
\hline Д.8.1 & $0,172 \pm 0,315$ & $0,344 \pm 0,394$ & $0,000 \pm 0,000$ \\
\hline Д.8.2 & $0,250 \pm 0,375$ & $0,156 \pm 0,248$ & $0,125 \pm 0,217$ \\
\hline Д.8.3 & $0,406 \pm 0,317$ & $0,000 \pm 0,000$ & $0,000 \pm 0,000$ \\
\hline Д.9.1 & $0,219 \pm 0,248$ & $0,359 \pm 0,467$ & $0,125 \pm 0,217$ \\
\hline Д.9.2 & $0,281 \pm 0,351$ & $0,203 \pm 0,253$ & $0,016 \pm 0,061$ \\
\hline Д.10.1 & $0,531 \pm 0,305$ & $0,313 \pm 0,225$ & $0,344 \pm 0,458$ \\
\hline Д. 10.2 & $0,188 \pm 0,272$ & $0,094 \pm 0,150$ & $0,609 \pm 0,256$ \\
\hline Д. 10.3 & $0,094 \pm 0,195$ & $0,063 \pm 0,188$ & $0,000 \pm 0,000$ \\
\hline 3.1 .1 & $0,203 \pm 0,296$ & $0,453 \pm 0,525$ & $0,016 \pm 0,061$ \\
\hline 3.1 .2 & $0,172 \pm 0,192$ & $0,250 \pm 0,217$ & $0,016 \pm 0,061$ \\
\hline 3.2 .1 & $0,203 \pm 0,283$ & $0,484 \pm 0,463$ & $0,141 \pm 0,293$ \\
\hline 3.2 .2 & $0,250 \pm 0,250$ & $0,297 \pm 0,296$ & $0,000 \pm 0,000$ \\
\hline 3.2 .3 & $0,141 \pm 0,233$ & $0,125 \pm 0,177$ & $0,266 \pm 0,312$ \\
\hline 3.2 .4 & $0,031 \pm 0,121$ & $0,016 \pm 0,061$ & $0,016 \pm 0,061$ \\
\hline 3.3 .1 & $0,000 \pm 0,000$ & $0,000 \pm 0,000$ & $0,109 \pm 0,216$ \\
\hline 3.3 .2 & $0,047 \pm 0,098$ & $0,141 \pm 0,250$ & $0,156 \pm 0,248$ \\
\hline 3.4 .1 & $0,250 \pm 0,331$ & $0,125 \pm 0,177$ & $0,203 \pm 0,283$ \\
\hline 3.4 .2 & $0,172 \pm 0,246$ & $0,000 \pm 0,000$ & $0,243 \pm 0,272$ \\
\hline П.1.1 & $0,234 \pm 0,286$ & $0,219 \pm 0,248$ & $0,016 \pm 0,061$ \\
\hline П.1.2 & $0,281 \pm 0,394$ & $0,000 \pm 0,000$ & $0,000 \pm 0,000$ \\
\hline П.2.1 & $0234 \pm 0,225$ & $0,172 \pm 0,170$ & $0,000 \pm 0,000$ \\
\hline П.2.2 & $0,141 \pm 0,197$ & $0,438 \pm 0,590$ & $0,016 \pm 0,061$ \\
\hline П.2.3 & $0,219 \pm 0,305$ & $0,000 \pm 0,000$ & $0,000 \pm 0,000$ \\
\hline П.3.1 & $0,406 \pm 0,305$ & $0,344 \pm 0,278$ & $0,109 \pm 0,216$ \\
\hline П.3.2 & $0,000 \pm 0,000$ & $0,000 \pm 0,000$ & $0,000 \pm 0,000$ \\
\hline П.3.3 & $0,109 \pm 0,293$ & $0,000 \pm 0,000$ & $0,000 \pm 0,000$ \\
\hline
\end{tabular}

Примітка. Середня кількість комах на $1 \mathrm{~m}^{2}$, розрахована за даними з 16 ділянок розміром $50 \times 50$ см на кожному полі.

Таблиця 4

Чисельність (екз./м²) Eurygaster integriceps (Puton, 1881), Aelia acuminata (Linnaeus, 1758),

Oulema lichenis (Heyden, 1879), Haplothrips tritici (Kurdjumov, 1912) на дослідних полях

Дніпропетровської, Запорізької та Полтавської областей $(\mathrm{x} \pm \mathrm{SD})$

\begin{tabular}{ccccc}
\hline $\begin{array}{c}\text { Екосистема, } \\
\text { умовна позначка }\end{array}$ & Eurygaster integriceps & Aelia acuminata & Oulema lichenis & Haplothrips tritici \\
\hline Д.1.1 & 2 & 3 & 4 & 5 \\
Д.1.2 & $0,125 \pm 0,217$ & $0,000 \pm 0,000$ & $0,016 \pm 0,061$ & $0,000 \pm 0,000$ \\
Д.2.1 & $0,000 \pm 0,000$ & $0,000 \pm 0,000$ & $0,000 \pm 0,000$ & $0,000 \pm 0,000$ \\
Д.2.2 & $0,000 \pm 0,000$ & $0,000 \pm 0,000$ & $0,000 \pm 0,000$ & $0,000 \pm 0,000$ \\
Д.2.3 & $0,000 \pm 0,000$ & $0,000 \pm 0,000$ & $0,000 \pm 0,000$ & $0,047 \pm 0,090$ \\
Д.2.4 & $0,031 \pm 0,121$ & $0,000 \pm 0,000$ & $0,000 \pm 0,000$ & $0,031 \pm 0,083$ \\
Д.3.1 & $0,031 \pm 0,083$ & $0,031 \pm 0,121$ & $0,016 \pm 0,061$ & $0,000 \pm 0,000$ \\
Д.3.2 & $0,000 \pm 0,000$ & $0,000 \pm 0,000$ & $0,000 \pm 0,000$ & $0,000 \pm 0,000$ \\
Д.3.3 & $0,125 \pm 0,217$ & $0,031 \pm 0,083$ & $0,000 \pm 0,000$ & $0,094 \pm 0,150$ \\
Д.3.4 & $0,172 \pm 0,229$ & $0,000 \pm 0,000$ & $0,094 \pm 0,214$ & $0,000 \pm 0,000$ \\
Д.4.1 & $0,000 \pm 0,000$ & $0,000 \pm 0,000$ & $0,000 \pm 0,000$ & $0,125 \pm 0,177$ \\
Д.4.2 & $0,172 \pm 0,229$ & $0,000 \pm 0,000$ & $0,141 \pm 0,152$ & $0,125 \pm 0,153$ \\
Д.4.3 & $0,422 \pm 0,303$ & $0,000 \pm 0,000$ & $0,125 \pm 0,234$ & $0,000 \pm 0,000$ \\
Д.5.1 & $0,156 \pm 0,263$ & $0,078 \pm 0,116$ & $0,000 \pm 0,000$ & 0,000 \\
Д.5.2 & $0,000 \pm 0,000$ & $0,109 \pm 0,152$ & $0,172 \pm 0,261$ & $0,328 \pm 0,000$ \\
Д.5.3 & $0,000 \pm 0,000$ & $0,094 \pm 0,150$ & $0,172 \pm 0,170$ & $0078 \pm 0,146$ \\
Д.6.1 & $0,188 \pm 0,207$ & $0,000 \pm 0,000$ & $0,000 \pm 0,000$ & $0,000 \pm 0,000$ \\
Д.6.2 & $0,219 \pm 0,248$ & $0,000 \pm 0,000$ & $0,000 \pm 0,000$ & $0,141 \pm 0,124$ \\
Д.6.3 & $0,266 \pm 0,272$ & $0,000 \pm 0,000$ & $0,000 \pm 0,000$ & $0,000 \pm 0,000$ \\
Д.6.4 & $0,250 \pm 0,293$ & $0,203 \pm 0,220$ & $0,031 \pm 0,083$ & $0,078 \pm 0,146$ \\
Д.7.1 & $0,000 \pm 0,000$ & $0,000 \pm 0,000$ & $0,000 \pm 0,000$ & $0,172 \pm 0,192$ \\
Д.7.2 & $0,391 \pm 0,293$ & $0,078 \pm 0,146$ & $0,125 \pm 0,125$ & $0,000 \pm 0,000$ \\
Д.7.3 & $0,500 \pm 0,319$ & $0,109 \pm 0,124$ & $0,203 \pm 0,237$ & $0,250 \pm 0,293$ \\
Д.7.4 & $0,266 \pm 0,272$ & $0,109 \pm 0,152$ & $0,000 \pm 0,000$ & $0,000 \pm 0,000$ \\
Д.8.1 & $0,109 \pm 0,176$ & $0,000 \pm 0,000$ & $0,016 \pm 0,061$ & $0,000 \pm 0,000$ \\
Д.8.2 & $0,000 \pm 0,000$ & $0,000 \pm 0,000$ & $0,000 \pm 0,000$ & $0,000 \pm 0,000$ \\
Д.8.3 & $0,156 \pm 0,291$ & $0,000 \pm 0,000$ & $0,000 \pm 0,000$ & $0,016 \pm 0,061$ \\
\hline
\end{tabular}




\begin{tabular}{|c|c|c|c|c|}
\hline 1 & 2 & 3 & 4 & 5 \\
\hline Д.9.1 & $0,328 \pm 0,339$ & $0,156 \pm 0,150$ & $0,000 \pm 0,000$ & $0,266 \pm 0,257$ \\
\hline Д.9.2 & $0,578 \pm 0,361$ & $0,000 \pm 0,000$ & $0,000 \pm 0,000$ & $0,000 \pm 0,000$ \\
\hline Д.10.1 & $0,156 \pm 0,263$ & $0,000 \pm 0,000$ & $0,000 \pm 0,000$ & $0,375 \pm 0,293$ \\
\hline Д.10.2 & $0,172 \pm 0,211$ & $0,219 \pm 0,232$ & $0,141 \pm 0,233$ & $0,000 \pm 0,000$ \\
\hline Д.10.3 & $0,000 \pm 0,000$ & $0,000 \pm 0,000$ & $0,000 \pm 0,000$ & $0,000 \pm 0,000$ \\
\hline 3.1 .1 & $0,188 \pm 0,207$ & $0,188 \pm 0,188$ & $0,016 \pm 0,061$ & $0,219 \pm 0,248$ \\
\hline 3.1 .2 & $0,016 \pm 0,061$ & $0,000 \pm 0,000$ & $0,203 \pm 0,417$ & $0,172 \pm 0,211$ \\
\hline 3.2 .1 & $0,266 \pm 0,348$ & $0,000 \pm 0,000$ & $0,000 \pm 0,000$ & $0,000 \pm 0,000$ \\
\hline 3.2 .2 & $0,000 \pm 0,000$ & $0,344 \pm 0,278$ & $0,219 \pm 0,263$ & $0,000 \pm 0,000$ \\
\hline 3.2 .3 & $0,406 \pm 0,278$ & $0,000 \pm 0,000$ & $0,000 \pm 0,000$ & $0,141 \pm 0,265$ \\
\hline 3.2 .4 & $0,203 \pm 0,345$ & $0,000 \pm 0,000$ & $0,016 \pm 0,061$ & $0,234 \pm 0,225$ \\
\hline 3.3 .1 & $0,188 \pm 0,300$ & $0,000 \pm 0,000$ & $0,000 \pm 0,000$ & $0,375 \pm 0,375$ \\
\hline 3.3 .2 & $0,250 \pm 0,250$ & $0,000 \pm 0,000$ & $0,000 \pm 0,000$ & $0,000 \pm 0,000$ \\
\hline 3.4 .1 & $0,016 \pm 0,061$ & $0,000 \pm 0,000$ & $0,000 \pm 0,000$ & $0,219 \pm 0,278$ \\
\hline 3.4 .2 & $0,203 \pm 0,283$ & $0,203 \pm 0,237$ & $0,047 \pm 0,098$ & $0,297 \pm 0,220$ \\
\hline П.1.1 & $0,250 \pm 0,293$ & $0,000 \pm 0,000$ & $0,000 \pm 0,000$ & $0,250 \pm 0,217$ \\
\hline П.1.2 & $0,000 \pm 0,000$ & $0,000 \pm 0,000$ & $0,000 \pm 0,000$ & $0,000 \pm 0,000$ \\
\hline П.2.1 & $0,000 \pm 0,000$ & $0,141 \pm 0,176$ & $0,000 \pm 0,000$ & $0,000 \pm 0,000$ \\
\hline П.2.2 & $0,016 \pm 0,061$ & $0,141 \pm 0,216$ & $0,031 \pm 0,083$ & $0,016 \pm 0,061$ \\
\hline П.2.3 & $0,000 \pm 0,000$ & $0,234 \pm 0,242$ & $0,125 \pm 0,153$ & $0,000 \pm 0,000$ \\
\hline П.3.1 & $0,016 \pm 0,061$ & $0,000 \pm 0,000$ & $0,000 \pm 0,000$ & $0,000 \pm 0,000$ \\
\hline П.3.2 & $0,031 \pm 0,083$ & $0,266 \pm 0,207$ & $0,094 \pm 0,150$ & $0,000 \pm 0,000$ \\
\hline П.3.3 & $0,000 \pm 0,000$ & $0,000 \pm 0,000$ & $0,000 \pm 0,000$ & $0,000 \pm 0,000$ \\
\hline
\end{tabular}

Примітка. Див. табл. 3.

Турун волосистий (Harpalus rufipes (De Geer, 1774)) - жук середніх розмірів, чорного кольору. Вусики і лапки у волосистої жужелиці руді з жовтуватим відтінком. Характерна риса - надкрила усіяні точками більш світлого відтінку і волосками. Максимальну діяльність цей жук проявляс у другій частині літа і восени, вечорами і вночі. Хоча турун волосистий $\epsilon$ важливим ентомофагом та винищувачем насіння бур'янів, у місцях концентрації особини даного виду здатні чинити істотний негативний вплив на посіви різних сільськогосподарських культур, пошкоджуючи генеративні та вегетативні органи рослин. Шкодить в основному імаго, поїдаючи незрілі зерна пшениці та інших зернових культур (Crowson, 1981; Guéorguiev, 1995).

Турун хлібний (Zabrus tenebrioides (Goeze, 1777)) вугільно-чорний жук із слабким металевим блиском, довжина тіла 14-16 мм. $€$ типовим мешканцем степової зони. Температури до $+30+36{ }^{\circ} \mathrm{C} \epsilon$ критичною для виду. Шкодить личинка, що живе в нірці поруч з кормовою рослиною. Вночі харчується на рослині. Для харчування вдень тягне листя в нірку. Пошкоджені личинками на ранніх стадіях розвитку рослини гинуть (Lindroth, 1974).

3 початком весняної вегетації до вищезазначених видів додаються п'явиця синя, смугаста хлібна та велика стеблова блішки й оленка пухнаста. Шкодочинність в цей період полягає у пошкодженні листової пластинки рослин (Vereshagin, 2001).

П'явиця синя (Oulema lichenis (Heyden, 1879)) - жук зеленувато-синього, синього або синьо-фіолетового, рідше чорного кольору з металевим блиском. Довжина тіла 304 мм. Дорослі жуки з'являються в кінці квітня - на початку травня, коли середньодобова температура досягає 9-10 ${ }^{\circ} \mathrm{C}$. Вони оселюються на крайових смугах полів шириною 25-30 м і прогризають листки злаків. Рослини мають пригнічений вигляд, відстають у рості та розвитку, у них зменшується розмір колосків і маса зернин. За чисельності сім - вісім жуків на 1 м² $^{2}$ посіву вони здатні знищувати до $15 \%$ листкової поверхні. Значну загрозу становлять личинки, які виплоджуються з яєць через 13-16 днів і живляться на тих самих рослинах, що й дорослі комахи (Orlov, 2006).

Смугаста хлібна блішка (Phyllotreta vittula (Redtenbacher, 1849)) - жук 1,5-2 мм завдовжки, чорний, голова та передньоспинка із зеленуватим або голубим металевим блиском. Уздовж кожного надкрилля жовта смуга. Яйця блідожовті, овальні, завдовжки 0,5 мм. Личинка близько 3,5 мм, біла, циліндрична. Лялечка дещо темніша за личинку. Пошкоджує пшеницю, ячмінь, жито, просо, кукурудзу, злакові трави. Найбільше пошкоджується перший листок, що спостерігається одразу після появи листка на поверхні. Молоді рослини пригнічуються, жовтіють, сохнуть. Найбільшої шкоди завдає неопушеним сортам м'якої пшениці, менше - кукурудзі та озимій пшениці. Личинки помітної шкоди зерновим злакам не завдають.

Велика стеблова блішка (Chaetocnema aridula (Gyllenhal, 1827)) - жук 1,8-2,8 мм завдовжки, темно-бронзового кольору iз зеленуватим відтінком. Пошкоджує озиму і яру пшеницю, ячмінь, жито, овес, злакові трави. Личинки проникають в стебла злаків і вигризають в них ходи, іноді навіть бувають в стеблах, що несуть колос. Найчастіше розвиваються в прикореневій частині стебел. Внаслідок пошкоджень жовтіє центральний лист, а пізніше і все стебло. Біля основи стебла $\epsilon$ вихідний отвір.

Оленка пухнаста (Tropinota hirta (Poda, 1761)) - чорний, майже матовий жук. Тіло широке, зверху сплощене, в довгих сірих, іноді жовтуватих волосках, що стирчать. Довжина - 8,4-16 мм, ширина - 4,7-7,7 мм. Найбільш шкідливі дорослі жуки в період спарювання. Особливо сильні пошкодження наносить в посушливі роки. Спалахи іiі розмноження вчені пов'язують із змінами ритму сонячної активності, а також однією з причин зростання чисельності оленки $є$ те, що всі стадії іiі розвитку пов'язані з грунтом (Orlov, 2006).

Середина вегетації збігається 3 фазами утворення колоска та наливу зерна. Найактивнішими шкідниками злакових культур в цей період вважається трипс пшеничний та мідляки (піщаний, кукурудзяний та широкогрудий).

Самки Haplothrips tritici (Kurdjumov, 1912) 1,3-1,5 мм завдовжки, від чорно-бурого до чорного кольору, самці трошки менші за самок, трапляються рідко. Масова поява дорослих трипсів збігається 3 початком колосіння озимої пшениці. Спочатку вони живляться колосковими лусками, а потім проникають у колос і починають відкладати яйця. На 6-8-му добу з них з'являються личинки, які спочатку висмоктують сік 3 колоскових лусок та квіткових плівок, а потім пошкоджують зерно, яке перебуває в м'якому стані. В результаті знижується маса і якість зерна, а загальні втрати можуть сягати $20 \%$ можливого врожаю (Stannard, 1968; Ananthakrishnan, 1980; Peñalver et al., 2012). 
Таблиця 5

Кількість виявлених представників 10 видів шкідників - фітофагів пшениці на території

Дніпропетровської, Запорізької та Полтавської областей (крім тих, які зазначені у табл. 3-4)

\begin{tabular}{|c|c|c|c|c|c|c|c|c|c|c|}
\hline \multirow[b]{2}{*}{ 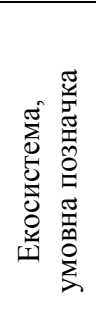 } & \multicolumn{10}{|c|}{ Кількість шкідників пшениці, шт. } \\
\hline & 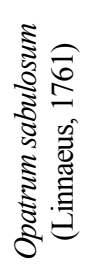 & 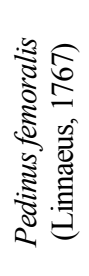 & 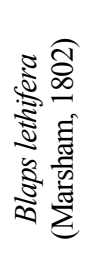 & 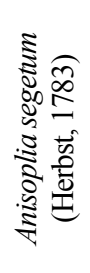 & 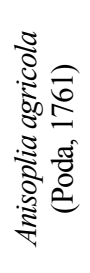 & 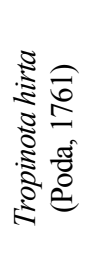 & 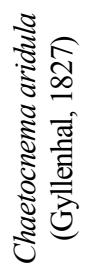 & 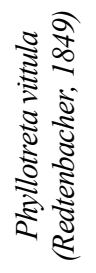 & 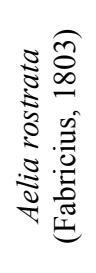 & 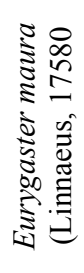 \\
\hline Д.1.1 & 0 & 5 & 1 & 0 & 0 & 1 & 0 & 1 & 1 & 0 \\
\hline Д.1.2 & 0 & 2 & 0 & 0 & 0 & 0 & 2 & 2 & 1 & 2 \\
\hline Д.2.1 & 1 & 0 & 0 & 0 & 0 & 0 & 1 & 1 & 0 & 0 \\
\hline Д.2.2 & 1 & 2 & 2 & 5 & 1 & 1 & 0 & 0 & 0 & 0 \\
\hline Д.2.3 & 0 & 0 & 1 & 1 & 0 & 3 & 1 & 2 & 2 & 2 \\
\hline Д.2.4 & 2 & 2 & 3 & 2 & 3 & 3 & 1 & 1 & 0 & 0 \\
\hline Д.3.1 & 0 & 2 & 2 & 1 & 0 & 0 & 0 & 1 & 1 & 1 \\
\hline Д.3.2 & 2 & 2 & 1 & 1 & 1 & 0 & 0 & 0 & 0 & 2 \\
\hline Д.3.3 & 1 & 0 & 0 & 0 & 0 & 2 & 1 & 1 & 3 & 0 \\
\hline Д.3.4 & 5 & 0 & 0 & 0 & 1 & 1 & 1 & 1 & 6 & 2 \\
\hline Д.4.1 & 0 & 4 & 1 & 1 & 0 & 0 & 0 & 0 & 0 & 0 \\
\hline Д.4.2 & 0 & 1 & 0 & 3 & 3 & 1 & 1 & 1 & 0 & 0 \\
\hline Д.4.3 & 0 & 0 & 0 & 0 & 0 & 0 & 1 & 1 & 0 & 1 \\
\hline Д.5.1 & 3 & 3 & 1 & 10 & 3 & 0 & 0 & 0 & 2 & 2 \\
\hline Д.5.2 & 1 & 1 & 1 & 1 & 0 & 0 & 0 & 0 & 2 & 0 \\
\hline Д.5.3 & 1 & 0 & 0 & 0 & 0 & 0 & 0 & 0 & 0 & 3 \\
\hline Д.6.1 & 0 & 0 & 0 & 4 & 0 & 0 & 1 & 1 & 0 & 0 \\
\hline Д.6.2 & 4 & 0 & 0 & 0 & 1 & 1 & 1 & 1 & 2 & 1 \\
\hline Д.6.3 & 0 & 1 & 3 & 0 & 3 & 0 & 0 & 0 & 2 & 2 \\
\hline Д.6.4 & 2 & 0 & 0 & 0 & 0 & 0 & 0 & 0 & 0 & 0 \\
\hline Д.7.1 & 0 & 0 & 0 & 0 & 0 & 0 & 0 & 0 & 0 & 0 \\
\hline Д.7.2 & 4 & 2 & 0 & 7 & 0 & 0 & 3 & 3 & 2 & 3 \\
\hline Д.7.3 & 1 & 2 & 2 & 2 & 2 & 0 & 0 & 0 & 4 & 0 \\
\hline Д.7.4 & 0 & 0 & 0 & 0 & 5 & 2 & 2 & 0 & 0 & 1 \\
\hline Д.8.1 & 1 & 1 & 1 & 2 & 1 & 1 & 3 & 2 & 0 & 0 \\
\hline Д.8.2 & 2 & 0 & 0 & 0 & 3 & 1 & 1 & 0 & 0 & 0 \\
\hline Д.8.3 & 0 & 0 & 0 & 1 & 1 & 0 & 0 & 0 & 0 & 0 \\
\hline Д.9.1 & 0 & 0 & 0 & 0 & 0 & 6 & 0 & 0 & 0 & 0 \\
\hline Д.9.2 & 1 & 3 & 3 & 0 & 0 & 0 & 1 & 1 & 0 & 1 \\
\hline Д.10.1 & 3 & 1 & 0 & 0 & 1 & 0 & 0 & 0 & 0 & 2 \\
\hline Д.10.2 & 1 & 1 & 1 & 0 & 2 & 3 & 3 & 3 & 0 & 1 \\
\hline Д.10.3 & 1 & 0 & 0 & 0 & 0 & 3 & 1 & 1 & 1 & 1 \\
\hline 3.1 .1 & 0 & 2 & 5 & 0 & 0 & 0 & 8 & 0 & 0 & 0 \\
\hline 3.1 .2 & 3 & 7 & 0 & 0 & 0 & 0 & 0 & 1 & 0 & 0 \\
\hline 3.2 .1 & 3 & 0 & 0 & 0 & 0 & 2 & 1 & 2 & 2 & 3 \\
\hline 3.2 .2 & 2 & 0 & 4 & 1 & 1 & 1 & 2 & 2 & 2 & 2 \\
\hline 3.2 .3 & 2 & 2 & 0 & 0 & 0 & 3 & 2 & 1 & 1 & 1 \\
\hline 3.2 .4 & 2 & 1 & 1 & 1 & 0 & 0 & 0 & 0 & 0 & 6 \\
\hline 3.3 .1 & 1 & 0 & 0 & 0 & 4 & 0 & 0 & 0 & 1 & 3 \\
\hline 3.3 .2 & 1 & 3 & 3 & 6 & 1 & 1 & 0 & 0 & 0 & 0 \\
\hline 3.4 .1 & 0 & 0 & 0 & 0 & 0 & 0 & 0 & 3 & 0 & 0 \\
\hline 3.4 .2 & 4 & 1 & 0 & 0 & 1 & 0 & 0 & 0 & 2 & 2 \\
\hline П.1.1 & 0 & 0 & 0 & 3 & 0 & 0 & 1 & 1 & 0 & 0 \\
\hline П.1.2 & 6 & 0 & 0 & 0 & 3 & 0 & 0 & 2 & 2 & 1 \\
\hline П.2.1 & 1 & 1 & 3 & 1 & 0 & 0 & 0 & 3 & 0 & 0 \\
\hline П.2.2 & 0 & 0 & 2 & 7 & 0 & 0 & 0 & 0 & 0 & 0 \\
\hline П.2.3 & 0 & 0 & 0 & 0 & 0 & 0 & 0 & 0 & 0 & 0 \\
\hline П.3.1 & 0 & 4 & 2 & 2 & 1 & 0 & 0 & 0 & 0 & 1 \\
\hline П.3.2 & 0 & 4 & 1 & 1 & 3 & 0 & 0 & 1 & 5 & 0 \\
\hline П.3.3 & 1 & 0 & 0 & 0 & 0 & 1 & 1 & 2 & 2 & 2 \\
\hline
\end{tabular}

Примітка. Кількість комах, які зафіксовані під час ручного розбирання проб на 16 ділянках розміром $50 \times 50$ см на кожному полі.

Мідляк піщаний (Opatrum sabulosum (Linnaeus, 1761)) жук розміром 7-10 мм, овальний, 3 майже паралельними боками, слабкоопуклий, чорний або сірувато-бурий від грунтової кірки, яка покриває все тіло. Найбільш значних пошкоджень жуки завдають у період з кінця квітня до середини травня, з'їдають верхівки сходів, а також перші листки. Жуки багатоїдні і пошкоджують різні культури. Личинки живляться гнильними рослинними рештками, живих рослин майже не пошкоджують.

Мідляк кукурудзяний (Pedinus femoralis (Linnaeus, 1767)) зустрічається рідше за піщаного. Жук 7,3-9,6 мм, тіло овальне, чорне, блискуче. Основну шкоду спричиняють 
личинки, які живуть в поверхневому шарі грунту; їдять висіяне насіння, сходи, коріння.

Мідляк широкогрудий (Blaps lethifera (Marsham, 1802)) жук розміром 20-27 мм, чорний, з витягнутим довгим тілом; голова опукла, матова, крупнопунктирована чорним; крил немає. Жуки пошкоджують сходи різних бур'янів, а також прив'ялі культурні рослини, особливо пшеницю, кукурудзу, соняшник, буряки. Личинки живляться висіяним насінням, сходами (Andersen, 1999).

Якісні показники врожаю злакових культур знижують шкідлива й маврська черепашка та елія носата й гостроголова. Перед самим збиранням зерно пошкоджують різні хлібні жуки родини пластинчастовусих (Scarabaeidae), зокрема кузька хлібний, жук хрестоносець та красун, або хрущ польовий (Belyaev, 1974).

Черепашка шкідлива (Eurygaster integriceps (Puton, 1881)). Тіло імаго широкоовальне, довжина 9-13 мм, ширина 6-7 мм; забарвлення варіює від світло-коричневого або світло-сірого до темно-сірого, в окремі роки чорного кольору. Відрізняється від інших шкідників дуже щільним захисним щитом, який вкритий візерунками. Пошкоджує всі колосові злаки, але найсильніше пшеницю та жито. У весняний період пошкодження призводить до загибелі центрального листа і стебла. Уколи в стебло викликають білоколосість та недорозвинення зерна. Дорослі клопи i личинки живляться також зерном. У місцях уколу утворюється темна пляма, зерно стає зморшкуватим, знижується його схожість (Brian, 1998; Parker et al., 2011; Armstrong et al., 2019).

Маврська черепашка (Eurygaster maura (Linnaeus, 17580)). Імаго і личинки зовні схожі на шкідливу черепашку; відрізняються дещо меншими розмірами тіла (8-11 мм); бокові краї передньоспинки прямі або дещо увігнуті. Пошкоджує пшеницю, жито, ячмінь, злакові трави, іноді просо, кукурудзу. Пошкодження негативно впливають на хлібопекарські якості зерна.

Елія гостроголова (Aelia acuminata (Linnaeus, 1758)) клоп яйцеподібної форми, 7-10 мм завдовжки, сіруватожовтого кольору. Личинки 1,6-6,7 мм, покриті короткими, добре помітними волосинками. Пошкоджує пшеницю, ячмінь, овес, кормові злакові трави. Шкоди завдають дорослі клопи, які перезимували, та їхнє потомство, однак найбільшої - личинки й клопи нового покоління, подібно до шкідливої черепашки та інших хлібних клопів. Завдана шкода стає відчутною при чисельності личинок 8-10 екз./м². На якість урожаю значною мірою впливають пошкодження в період фази молочної стиглості зерна включно до закінчення збирання врожаю.

Елія носата (Aelia rostrata (Fabricius, 1803)) має жовтувате тіло, завдовжки 10-12 мм, 3 малюнком iз поздовжніх темних i світлих смуг, голова у вигляді трикутника 3 витягнутими вперед вилицями. Личинки до 7,5 мм завдовжки, жовтувато-білі, 3 темними, часто розмитими смугами, без опушення. Пошкоджує переважно пшеницю. Шкоди завдають дорослі клопи й личинки: перші знижують кількість урожаю, другі - його якість. Зовнішні ознаки пошкодження рослин i зерна подібні до тих, що завдають інші черепашки, однак їх негативний вплив на якість урожаю значно менший (Hinton, 1981).

Красун, або хрущ польовий (Anisoplia segetum (Herbst, 1783)) - жук 8-10 мм завдовжки, синювато-чорний 3 металевим блиском, черевце і надкрила коричнево-жовті, без малюнка, 3 твердими шипами по краях. Личинка розміром 25-30 мм, С-подібна, біла, голова жовто-бура, на задній частині анального тергіту 3 дещо витягнутою площинкою. Жуки пошкоджують пиляки, а також зав’язі та зерна на початку наливання в колосках жита, пшениці; личинки пошкоджують корені буряків, соняшнику, тютюну, бульби картоплі; сіянці яблуні, груші, сливи, вишні.

Кузька хлібний (Anisoplia austriaca (Herbst, 1783)) - жук 12,8-16 мм завдовжки, тіло синювато-чорне з металевим блиском. Личинка розміром до 35 мм, С-подібно зігнута, біла, з буро-жовтою головою, 4-членистими вусиками й ногами. Жук виїдає зерна злаків у період молочної стиглості, а тверді зерна вибиває на грунт. Особливо сильно пошкоджує пшеницю, жито, ячмінь, живиться зернами диких злаків. Личинки пошкоджують корені жита, пшениці.

Жук хрестоносець (Anisoplia agricola (Poda, 1761)) - жук 10,5-13 мм завдовжки, чорний із зеленуватим металевим блиском; надкрила буро-жовті з чорним малюнком у вигляді хреста, який може повністю редукуватися. Личинка розміром до 28 мм, жовтувато-біла, дугоподібно вигнута, м'ясиста, 3 коричневою головою i добре розвиненими ногами. Жуки пошкоджують недозрілі зерна пшениці, жита, ячменю, могару; личинки - бульби картоплі, корені буряків, зернових злаків (Belyaev, 1974; Kř́stek, 1991).

В результаті контролю чисельності та видового складу шкідників - фітофагів пшениці необхідно адаптувати застосування інтегрованих методів захисту пшениці до грунтово-кліматичних умов степової та лісостепової зони України.

\section{Висновки}

У результаті обстеження 50 агроценозів на території Дніпропетровської, Запорізької та Полтавської областей сформовано список найпоширеніших шкідників пшениці, який включає 17 видів 37 родин. Середня чисельність комах кожного 3 цих видів на $1 \mathrm{~m}^{2}$ посівів пшениці перевищила позначку 0,310 екз./ $\mathrm{m}^{2}$. Серед виявлених фітофагів найчастіше зустрічаються Harpalus rufipes (De Geer, 1774) - 88 \% заражених полів, Zabrus tenebrioides (Goeze, 1777) - 78 \% та Anisoplia austriaca (Herbst, 1783) 72 \%. До менш численних належать Eurygaster integriceps (Puton, 1881) - $68 \%$, Haplothrips tritici (Kurdjumov, 1912) $44 \%$, Oulema lichenis (Heyden, 1879) - 42\% та Aelia acuminata (Linnaeus, 1758) - $36 \%$. Інші 10 видів виявлені в невеликій кількості (в середньому 2-4 особини). За результатами аналізу наведена коротка характеристика кожного 317 видів шкідників - фітофагів з урахуванням їх шкодочинності в різні періоди вегетації пшениці. В результаті контролю чисельності та видового складу шкідників - фітофагів пшениці необхідно адаптувати застосування інтегрованих методів захисту пшениці до грунтово-кліматичних умов степової та лісостепової зони України.

\section{References}

Ananthakrishnan, T. N. (1980). Thrips. In: Harris, K. F. \& Maramorosch, K. (Ed.). Vectors of Plant Pathogens. Academic Press, New York. Pp. 149-164.

Andersen, A. (1999). Plant protection in spring cereal production with reduced tillage. II. Pests and beneficial insects. Crop Protection, 18, 651-657.

Armstrong, P., Maghiran, E. \& Ozulu, M. (2019). Determining damage levels in wheat caused by Sunn pest (Eurygaster integriceps) using visible and near-infrared spectroscopy. Journal of Cereal Science, 86, 102-107.

Bej-Bienko, G. (1964). Opredelitel nasekomyh Evropejskoj chasti SSSR [Key to insects of the European part of the USSR]. Nauka, Moskcow, Vol. 1, 2 (in Russian).

Belyaev, I. M. (1974). Vrediteli zernovyh kultur [Pests of cereals]. Kolos, Moskcow (in Russian).

Brian, R. C. (1998). Literature review of sunn pest Eurygaster integriceps Put. (Hemiptera, Scutelleridae). Crop Protection, 17, 271-287.

Crowson, R. A. (1981). Herbivorous beetles. In: The biology of the Coleoptera, Academic Press, London. Pp. 584-618.

Getman, M. V. (2008). Mexanizmy ta dzherela stijkosti pshenyci proty osnovnyx shkidnykiv [Mechanisms and sources of wheat resistance against major pests]. Protection and Quarantine of Plants, 54, 106-126 (in Ukrainian). 
Guéorguiev, V. B., \& Guéorguiev, B. V. (1995). Catalogue of the Ground-beetles of Bulgaria (Coleoptera, Carabidae). Pensoft Publishers, Sofia-Moscow. Pp. 166-168.

Halimonik, P. M. (2005). Zahyst roslyn: probleyi i perspektyvy [Plant Protection: problems and prospects]. Quarantine and plant protection, 1, 4-8 (in Ukrainian).

Hinton, H. (1981). Hemiptera. In: Biology of Insect Eggs. Oxford unsver press, Oxford. 565-641.

Křístek, J, (1991). Selected groups of insects and harvestmen. Developments in Agricultural and Managed Forest Ecology, 15B, 451-468.

Lindroth, C. (1974). Coleoptera. Carabidae. Handbooks for the Identification of British Insects. Royal Entomological Society, London.

Maslak, O., Ilchenko, V., \& Ilchenko, O. (2016). Efektyvnist vyroshuvannya pshenyci ozymoyi [Efficiency of cultivation of winter wheat]. Agronomy Today, 4, 7-13 (in Ukrainian).

Orlov, V. N. (2006). Vrediteli zernovyh kolosovyh kultur [Pests of cereal crops]. Pechatnyy Gorod, Moskow (in Russian).
Parker, B., Amir-Maafi, M., Skinner, M., Kim, J., \& Bouhssini, M. (2011). Distribution of Sunn Pest, Eurygaster integriceps Puton (Hemiptera: Scutelleridae), in overwintering sites. Journal of Asia-Pacific Entomology, 14, 83-88.

Peñalver, E., Labandeira, C., Barrón, E., Delclòs, X., \& Nel, P. (2012) Thrips pollination of Mesozoic gymnosperms. Proceedings of the National Academy of Sciences, 109(22), 8623-8628.

Romanenko, O., Bobrujko, N., Dudaryeva, G., \& Romanenko, N. (2001). Sti jkist sortiv ozymoyi pshenyci shodo hvorob ta shkidnykiv u stepovij zoni [Stability of winter wheat varieties against diseases and pests in the steppe zone]. Plant Protection, 10, 8-9 (in Ukrainian).

Stannard, L. (1968). The thrips, or Thysanoptera, of Illinois. Illinois Natural History Survey, 21, 215-552.

Vasilev, V. P. (1989). Vrediteli selskohozyajstvennyh kultur i lesnyh nasazhdenij [Pests of crops and forest plantations]. Urozhay, Kiev (in Russian).

Vereshagin, L. N. (2001). Vrediteli i bolezni zernovyh kolosovyh kultur [Pests and diseases of cereal crops]. Yunivest Marketing, Kiev (in Russian). 